\title{
HUBUNGAN KETUBAN PECAH DINI DENGAN KEJADIAN ASFIKSIA
}

\section{LITERATURE REVIEW: THE CORRELATION OF PREMATURE RUPTURE OF MEMBRANES (PROM) WITH THE INCIDENCE OF ASPHYXIA}

\author{
Hanny Yuli Andini, Lara Santi Indah Lestari, Ninda Sulastin \\ Poltekes TNI AU Ciumbuleuit Bandung
}

(hannyyuliandini@gmail.com)

\begin{abstract}
ABSTRAK
Menurut Human Development Report tahun 2010 Ketuban Pecah Dini (KPD) di Indonesia berkisar 4,4-7,6\% dari seluruh kehamilan dengan KPD berkisar antara 3-18\% yang terjadi pada kehamilan preterm, sedangkan pada kehamilan aterm sekitar $8-10 \%$. Menurut beberapa peneliti KPD dapat menyebabkan terjadinya asfiksia. Penelitian ini bertujuan untuk mengetahui hubungan ketuban pecah dini dengan kejadian asfiksia. Jenis penelitian yang digunakan adalah kepustakaan atau kajian literatur. Data penelitian ini berasal dari data sekunder, yaitu berasal dari beberapa sumber penelitian yang terdiri dari 25 sumber yang terdiri dari 7 jurnal ilmiah, 3 jurnal internasional, 5 skripsi/tesis, dan 10 buku. Pencarian sumber menggunakan google scholar, microsoft academic, media meneliti, and google. Dari penelitian ini didapatkan bahwa penyebab terjadinya asfiksia yang disebabkan oleh faktor langsung maupun faktor tidak langsung. Faktor langsung tersebut adalah KPD itu sendiri. Sedangkan, untuk faktor yang tidak langsung adalah CPD dan usia kehamilan. Sehingga asfiksia yang disebabkan kedua faktor tersebut dapat memperburuk keadaan terjadinya asfiksia. Dari salah satu penelitian dalam negeri oleh peneliti Anisa di daerah Kediri didapatkan angka kejadian asfiksia sebanyak $53 \%$ oleh ibu yang mengalami KPD. Berdasarkan hasil penelitian dari dalam negeri dan luar negeri dengan rata-rata $p$ value $\leq 0,005$, sehingga didapatkan kesimpulan terdapat hubungan antara ketuban pecah dini dengan kejadian asfiksia.
\end{abstract}

Kata kunci: Ketuban pecah dini (KPD), asfiksia

\section{ABSTRACT}

According to Human Development Report year 2010 for Premature Rupture Of The Membranes (PROM) in Indonesia ranging from 4.4-7.6\% of all pregnancies with PROM ranging from $3-18 \%$ that occur in preterm pregnancies, while in term pregnancies around 8-10\%. According to some researchers, it can cause asphyxia. This study aims to determine the correlation of premature rupture of membranes with the incidence of asphyxia. The type of research used literature or literature study. This research data comes from secondary data, which is derived from several research sources consisting of 25 sources consisting of 7 scientific journals, 3 international journals, 5 theses / theses, and 10 books. Source search uses Google Scholar, Microsoft Academic, media research, and Google. From this study it was found that the causes of asphyxia were caused by both direct and indirect factors. The direct factor is to PROM. Meanwhile, the indirect factors are CPD and gestational age. So that asphyxia caused by these two factors can worsen the condition of asphyxia. From one study in the country by researchers Anisa at Kediri established in the incident as much as 53\% by the mother who experienced PROM. Based on research results from domestic and abroad with an average of $p$ value. So found the conclusion there are correlation between PROM on the incident asphyxia.

Keywords: Premature Rupture Of The Membranes (PROM), asphyxia 


\section{PENDAHULUAN}

Menurut (WHO) World Health Organization tahun 2013 kejadian KPD (Ketuban Pecah Dini) di dunia berkisar 50$60 \%$. KPD di Indonesia berkisar 4,4-7,6\% dari seluruh kehamilan angka kejadian KPD berkisar antara 3-18\% yang terjadi pada kehamilan preterm, sedangkan pada kehamilan aterm sekitar 8-10\% (Human Development Report, 2010). Menurut WHO kejadian KPD di Indonesia pada tahun 2013 sebanyak 35\% (WHO, 2014). Di Jawa Barat sendiri pada tahun 2014 kejadian ketuban pecah dini masih belum hilang yaitu sekitar $5,5 \%$.

Ketuban pecah dini (KPD) atau ketuban pecah sebelum waktunya (KPSW) sering disebut dengan Premature Rupture of the Membrane (PROM) didefinisikan sebagai pecahnya selaput ketuban sebelum waktunya melahirkan dengan usia kehamilan aterm.

Salah satu komplikasi KPD pada bayi baru lahir adalah kompresi tali pusat dan sindrom gangguan pernapasan, yaitu faktor yang bisa mengakibatkan terjadinya asfiksia neonatorum.

Menurut WHO tahun 2012 angka kejadian asfiksia sebesar $21,1 \%$, di Indonesia tahun 2015, angka kejadian asfiksia sebesar 41,94\%. Menurut dinas kesehatan Di Provinsi Jawa Barat angka kejadian asfiksia tahun 2014 ialah 25,2\%. Masih tingginya angka kejadian asfiksia menyebabkan angka kematian bayi sulit ditekan. Karena asfiksia termasuk penyebab kematian paling umum di dunia.

Asfiksia adalah kegagalan untuk memulai dan melanjutkan pernapasan secara spontan dan teratur pada saat bayi baru lahir atau beberapa saat sesudah lahir. Bayi mungkin lahir dalam kondisi asfiksia (asfiksia primer) atau mungkin dapat bernapas tetapi kemudian mengalami asfiksia beberapa saat setelah lahir (asfiksia sekunder).

Pada kejadian ketuban pecah dini, kompresi tali pusat merupakan salah satu komplikasi yang mengakibatkan terjadinya asfiksia neonatorum karena gangguan aliran dalam tali pusat. Sehingga adanya gangguan pertukaran gas untuk oksigen dan karbondioksida.

"Pada ibu bersalin dengan KPD terdapat bekisar 25\% bayi yang memiliki asfiksia ringan/tidak asfiksia, 58,30\% bayi yang memiliki asfiksia sedang, 16,66\% bayi yang memiliki asfiksia berat".

Penelitian tersebut didapatkan berdasarkan hasil penelitian yang dilakukan dilakukan oleh Putri di daerah Kendal pada tahun 2020.

\section{METODE PENELITIAN}

Desain penelitian ini menggunakan Literature Review. Data yang digunakan pada penelitian ini adalah data sekunder, yang 
berarti data yang diperoleh dari hasil penelitian yang telah dilakukan oleh penelitipeneliti terdahulu. Teknik pengumpulan data menggunakan studi literatur.

\section{HASIL DAN PEMBAHASAN}

Dari beberapa jurnal yang dijadikan sebagai landasan literatur ini didapatkan angka kejadian Ketuban Pecah Dini (KPD) sebanyak $44 \%$ di Iran, 34\% di Singapura 38\% di Myanmar. Sedangkan untuk di Indonesia sendiri yang diperoleh dari beberapa jurnal didapatkan angka 35\% di daerah Surabaya.

Faktor-faktor terjadinya KPD yang diteliti dalam beberapa jurnal penelitian ini diantaranya usia ibu, overditensi uterus, serviks inkompeten, CPD, paritas, usia kehamilan, , anemia, dan riwayat KPD sebelumnya, infeksi

Pada kejadian KPD, paritas merupakan salah satu faktor terjadinya KPD. Paritas adalah jumlah anak yang pernah dilahirkan oleh ibu. Paritas yang memiliki resiko yang tinggi yaitu ibu dengan grandemultipara yang berarti ibu dengan paritas $>4$. Ibu yang telah melahirkan beberapa kali lebih berisiko mengalami KPD karena vaskularisasi pada uterus mengalami gangguan yang mengakibatkan jaringan ikat selaput ketuban mudah rapuh dan akhirnya pecah spontan.

Usia ibu biasanya sejalan dengan paritas namun tidak semua. Biasanya ibu yang memiliki usia >35 tahun memiliki paritas tinggi. Namun usia ibu bukan faktor utama terjadinya KPD, melainkan usia ibu merupakan faktor pendukung yang dapat menyebabkan faktor lain untuk terjadinya KPD. Usia beresiko pada ibu hamil terjadi pada usia $<20$ tahun atau $>35$ tahun. Usia ibu $<20$ tahun ibu masih dalam emosi yang tidak stabil sehingga belum siap menerima menjadi ibu dan ketidaksiapan organ untuk melahirkan juga merupakan faktor resiko dalam kehamilan. Sedangkan untuk usia ibu $>35$ tahun secara organ reproduksi ibu mengalami kemunduran dan sering juga ditambah dengan penyakit lain sehingga memperburuk keadaan.

Faktor terjadinya KPD yang didukung oleh usia ibu yaitu, serviks inkompeten, infeksi, dan CPD. Terjadinya serviks inkompeten biasanya terjadi pada usia ibu $>20$ tahun sampai 35 tahun. Serviks inkompeten adalah suatu kondisi dimana kelenturan leher rahim untuk menahan kehamilan hilang. Hal ini terjadi akibat persalinan yang berulang dan riwayat curettage. Karena kurang kuatnya leher rahim untuk menahan hasil konsepsi sehingga rentan terjadi ketuban pecah dini.

Selanjutnya yang merupakan faktor pendukungnya usia adalah infeksi. Infeksi tersebut yaitu korioamnionitis yang merupakan keadaan pada perempuan hamil dimana korion, amnion dan cairan ketuban terkena infeksi bakteri. Korioamnionitis merupakan komplikasi serius bagi ibu dan janin, bahkan dapat berlanjut menjadi sepsis. 
Membran khorioamnionitik terdiri dari jaringan viskoelastik. Apabila jaringan ini dipacu oleh persalinan atau infeksi maka jaringan akan menipis dan sangat rentan untuk pecah disebabkan adanya aktivitas enzim kolagenolitik.

Selain serviks inkompeten dan infeksi, Cephalopelvic disproportion (CPD) yaitu suatu bentuk ketidaksesuaian antara ukuran kepala janin dengan panggul ibu juga merupakan faktor KPD yang didukung oleh usia ibu yang bisa mengakibatkan KPD. KPD yang disebabkan oleh CPD terjadi karena kepala terlalu besar atau bahu yang tidak dapat memasuki pintu panggul. Kesukaran ini mengakibatkan terjadinya ketuban pecah dini pada saat persalinan karena tidak adanya bagian terendah yang menutupi PAP. Hal ini mengakibatkan meningkatnya tekanan terhadap membran bagian bawah sehingga besar kemungkinan terjadi ketuban pecah sebelum waktunya terjadi persalinan dengan prematur.

Oleh karena itu, prematur merupakan akibat dari KPD, sehingga secara tidak langsung usia kehamilan juga merupakan faktor yang dapat menyebabkan terjadinya KPD.

Selain itu overdistensi uterus juga merupakan faktor terjadinya KPD. Overdistensi uterus yaitu tekanan intrauterine yang meningkat. Misalnya hidramnion dan kehamilan gemeli. Perubahan volume cairan amnion berhubungan erat dengan hasil akhir kehamilan, karakteristik janin maupun ibu. Komplikasi yang sering terjadi pada polihidramnion adalah malpresentasi janin, ketuban pecah dini, prolaps tali pusat, persalinan preterm dan gangguan pernafasan pada ibu. Adanya keregangan otot rahim menyebabkan tekanan intra uterin meningkat sehingga mudah terjadi robekan pada selaput ketuban atau uterin amniotik dan akhirnya dapat terjadi persalinan dengan KPD.

Faktor yang lainnya yang terdapat dalam jurnal penelitian ini namun tidak terdapat dalam buku yaitu riwayat KPD sebelumnya dan anemia. Wanita yang mengalami KPD pada kehamilan atau menjelang persalinan maka pada kehamilan berikutnya akan lebih berisiko mengalaminya kembali antara 3-4 kali dari pada wanita yang tidak mengalami KPD sebelumnya karena komposisi membran yang menjadi mudah rapuh dan kandungan kolagen yang semakin menurun pada kehamilan berikutnya.

Selanjutnya terjadi pada ibu dengan anemia. Anemia pada kehamilan menyebabkan berkurangnya massa hemoglobin di dalam jaringan sehingga tidak mampu memenuhi fungsinya sebagai pembawa oksigen keseluruh tubuh. Kurangnya oksigenasi terutama jaringan ketuban akibatnya menimbulkan kerapuhan pada selaput ketuban.

Dalam beberapa jurnal penelitian ini komplikasi yang terjadi pada janin dengan ibu yang KPD yaitu asfiksia. Asfiksia yang 
terjadi di beberapa Negara luar dengan angka kejadian 28\% di Iran, 3,2\% di Singapura, 22\% di Myanmar. Sedangkan untuk di Indonesia sendiri yang diperoleh dari beberapa jurnal didapatkan angka 25\% di daerah Gresik.

Asfiksia adalah keadaan dimana bayi tidak dapat segera bernafas secara spontan dan teratur setelah lahir. Faktor terjadinya asfiksia pada penelitian ini memiliki hubungan secara tidak langsung diantaranya partus lama, usia kehamilan, BBLR, dan status gizi ibu sedangkan faktor yang memiliki hubungan langsung yaitu KPD nya itu sendiri.

Faktor langsung yang dapat menyebabkan asfiksia itu sendiri yaitu KPD. KPD pada kejadian asfiksia terjadi karena terjadinya oligohidramnion yang menekan tali pusat sehingga tali pusat mengalami penyempitan dan aliran darah yang membawa oksigen ibu ke bayi terhambat sehingga menimbulkan asfiksia neonatorum.

Sehingga dapat disimpulkan dari 25 sumber yang terdiri dari 10 jurnal, 5 tugas akhir, dan 10 buku (yang terdapat dalam pembahasan). Dari 3 negara luar diantaranya Iran, Singapura, Myanmar kejadian KPD tertinggi berada di Negara Iran, yaitu sebesar $44 \%$. Sedangkan untuk di dalam negeri kejadian KPD tertinggi berada di daerah Surabaya, yaitu sebesar $35 \%$.

Untuk kejadian asfiksia dari ketiga Negara seperti di atas diperoleh hasil kejadian asfiksia tertinggi berada di Negara Singapura dengan angka kejadian 3,2\%. Sedangkan untuk di Indonesia sendiri angka kejadian asfiksia tertinggi berada di Gresik dengan angka kejadian $25 \%$. Dari dalam negeri dan luar negeri kejadian asfiksia tertinggi terjadi pada asfiksia rendah dengan angka kejadiannya lebih dari setengahnya angka kejadian asfiksia seluruhnya.

KPD dapat menyebabkan terjadinya asfiksia yang disebabkan oleh faktor yang berhubungan secara langsung maupun yang tidak langsung.

\section{KESIMPULAN DAN SARAN}

Berdasarkan frekuensi kejadian Ketuban Pecah Dini (KPD) dari 25 sumber yang telah dilakukan literature 3 negara, diantaranya Iran, Singapura, Myanmar. Diperoleh angka kejadian kpd tertinggi di Iran sebesar $44 \%$. Dari sekian penelitian yang dibaca untuk di Indonesia KPD tertinggi diperoleh angka kejadian 35\% di daerah Surabaya.

Berdasarkan frekuensi kejadian asfiksia dari 25 sumber yang telah dilakukan literature 3 negara, diantaranya Iran, Singapura, Myanmar. Diperoleh angka kejadian tertinggi asfiksia di Singapura sebesar 3,2\%. Untuk di Indonesia asfiksia tertinggi diperoleh angka kejadian 25\% di daerah Gresik.

Berdasarkan hubungan Ketuban Pecah Dini (KPD) dengan kejadian asfiksia dari 25 sumber yang telah dilakukan literature. Didapatkan bahwa terdapat hubungan antara 
kpd dengan kejadian asfiksia untuk di Negara Myanmar dengan $\mathrm{p}$ value 0,000 dengan RR 2 kali lebih besar. Sedangkan untuk di Indonesia sendiri didapatkan $\mathrm{p}$ value $0,000 \mathrm{di}$ daerah Denpasar dengan RR 5 kali lebih besar.

Pada penelitian ini saya menggunakan $e$-book namun penggunaan e-book tidak maksimal dikarenakan ada beberapa halaman yang tidak bisa terbuka. Sehingga akan lebih mudah apabila fasilitas perpustakaan kampus menyediakan e-library sehingga mempermudah akses mahasiswa untuk mendapatkan sumber (buku). Diharapkan peneliti selanjutnya menambahkan sumber lainnya yang didapatkan dengan hasil penelitian sendiri di lapangan.

\section{DAFTAR PUSTAKA}

bab I Pendahuluan. Dapat Diakses: Http://Scholar.Unand.Ac.Id/37794/2/ Bab\%25201.Pdf\&Ved=2ahukewilqer zsbfnah.

Untitled_Kementrian Kesehatan 2014 [Dikunjungi 02 Desember 2019]. Dapat Diakses:

Zwww.Depkes.Go.Id/Resources/Do wnload/Profil/Profil_Kesprovinsi_20 14/12 Jabar 2014.Pdf\&Ved2ahukewih=Hifb.

Putri M. 2016. Ketuban Pecah Dini Pada Kehamilan Preterm [Dikunjungi 08 Desember 2019]. Dapat Diakses: Www.Respository.Lpppm.Unila.Ac.I d/2215/1/Muflikha_Sofiana_Putri_11 801107_9_2016_06_05_17_38_58_4 $52 \% 25281 \% 2529$.Pdf\&Ved.

L R. Ketuban Pecah Dini 20192019 [Dikunjungi 08 Desember 2019].
Dapat Diakses:

Https://Lusa.Afkar.Id/Ketuban-

Pecah-Dini-Kpd.

Azizah N. 2013.Hubungan Antara Ketuban Pecah Dini Dan Kejadian Asfiksia Pada Bayi Baru Lahir. Jurnal Eduhealth.

Wulandari P. Faktor-Faktor Yang Berhubungan Dengan Kejadian Asfiksia Neonatorum Di Ruang Melati Rsud Dr.H.Soewondo Kendal [Dikunjungi 23 Januari 2020]. Dapat Diakses:

Https://Media.Neliti.Com/Media/Pub lications/91529-Id-Faktor-Faktor-

YangberhubunganDengan.Pdf\&Ved=2ahukewiryfnmjlj nahxryiskhw7ua0qf.

Fitrianingsih Y. Bab I Pendahuluan 2014 [Dikunjungi 23 Januari 2020]. Dapat Diakses:

Http://Repository.Maranatha.Edu/237 88/3/1410163 Chapter1.Pdf\&Ved=2 ahukewjjtvt2jbjnahwcfh0khey9bd0qf jaaegqibba.

Nur W. 2010. Asuhan Neonatus Bayi Dan Balita. Yogyakarta: Fitramaya; Ketuban Pecah Dini Di Rumah Sakit Umum Daerah Unggaran Higeia Journal Of Public Health Research And Development. 2018.RN.

Puspitasari R. 2019. Korelasi Karakteristik Dengan Penyebab Ketuban Pecah Dini Pada Ibu Bersalin Di Rsu Densia Greseik. Indonesian Journal For Helath.

Hidayat. BAB I PENDAHULUAN 2019 [dikunjung 04 Januari 2020]. dapat diakses https://digilib.esaunggul.ac.id.

Sukarni I. 2014. Patologi Kehamilan, Persalinan, Nifas, dan Neonatus Resiko Tinggi. Yogyakarta: Nuha Medika.

Chandranita I. 2009. Buku Ajar Patologi Obstetri Untuk Mahasiswa Kebidanan. Jakarta: Buku Kedokteran EGC.

Hidayat A. Penjelasan Desain Penelitian (Pengantar) 2012 [dikunjungi 04 
Januari 2020]. dapat diakses: www.google.com/amp/s/www.statisti kian.com/2020/05/desain-penelitianpengantar.html/.

Yeyeh Ai. 2010 Asuhan Kebidanan 4 (Patologi). Jakarta: CV Trans Info Media

Yuliasari D. Hubungan Ketuban Pecah Dini dan Asfiksia [dikunjungi 20 Juni 2020]. Dapat diakses: http://www.ejurnalmalahayati.ac.id/i ndex.php/analisfarmasi/article/view/1 $\underline{170}$

Romi S. Pengantar Literature Review. [cited 202020 Juni] Available from: https://romisatriawahono.net/2016/05 /15/systematic-literature-reviewpengantar-tahapan-dan-studi-kasus/

Ruki M. Metode Penelitian. [dikunjungi 20 Juni 2020] dapat diakses: https://metodepenelitiana.wordpress.c om/literature-review-2/

Manuaba, IBG. 2010. Ilmu Kebidanan, Penyakit, Kandungan dan KB Untuk Pendidikan Bidan. Jakarta: EGC

Manuaba, dkk. 2010. Pengantar Kuliah Obstetri. Jakarta: EGC

Saifudin, dkk. 2010. Buku Panduan Praktis Pelayanan Kontrasepsi. Jakarta: Yayasan Bina Pustaka Sarwono

Cunningham, F.G et al. 2012. Obstetri Williams, Ed.23, vol.2. Jakarta: EGC

Wiknjosastro, 2010. Asuhan Persalinan Normal \& Inisiasi Menyusu Dini. Jakarta: Yayasan Bina Pustaka

Prawirohardjo, Sarwono. 2010. Ilmu Kebidanan. Jakarta: Yayasan Bina Pustaka Sarwono Prawiroharjo

Yulita H. Faktor Penyebab Ketuban Pecah Dini (KPD) 2016 [dikunjungi 25 juni
2020]. Dapat diakses: https://www.google.com/url?sa=t\&so urce=web\&rct=j\&url=https://reposito ry.poltekes-

kdi.ac.id/174/1/KTI\%2520JULIANT

I\%2520RAHAYU\%2520\%2528NIM $\% 2520 \mathrm{P} 00324012051 \% 2529 . \mathrm{pdf}$

Jumlah Paritas dan Anemia sebagai Faktor Prediktor Kejadian Ketuban Pecah Dini. Jurnal UMS. 2014. Irsam, dkk.

Rukiyah, AY dkk. 2013. Asuhan Neonatus Bayi dan Anak Balita. Jakarta: Trans Info Media

Purnamaningrum Y E. 2010. Penyakit Pada Neonatus, Bayi dan Balita. Yogyakarta: Fitramaya

Nugroho, T. 2012. Patologi Kebidanan. Jakarta: Nuha Medika.

Oxorn, Harry dkk. 2010. Ilmu Kebidanan Patologi \& Fisiologi Persalinan human labour and birth. Jakarta: Yayasan Essentia Medica

Faktor Yang Mempengaruhi Ketuban Pecah DIni. Jurnal Vokasi Kesehatan. 2016. Maria, dkk.

Wiknjosastro, H. 2012. Ilmu Kebidanan. Jakarta: Yayasan Bina Pustaka Sarwono

Muslihatun, WN. 2010. Asuhan Neonatus Bayi Dan Balita. Yogyakarta: Fitramaya

Sukarni, I. 2014. Patologi Kehamilan, Persalinan, Nifas, dan Neonatus Resiko Tinggi. Yogyakarta: Nuha Medika 